\title{
Production of reactive oxygen metabolites induced by asbestos fibres in human polymorphonuclear leucocytes
}

\author{
M HEDENBORG, M KLOCKARS \\ From the Institute of Occupational Health, Helsinki, Finland
}

SUMMARY The ability of quartz and various asbestos fibres to induce the production of reactive oxygen metabolites in human polymorphonuclear leucocytes was assessed. A chemiluminescence assay showed that the activation of polymorphonuclear leucocytes was induced in the following order of effect: quartz; chrysotile A; crocidolite; chrysotile B; amosite; and anthophyllite. Only slight chemiluminescence was produced by cells exposed to wollastonites and titanium dioxide. A positive correlation was seen between production of chemiluminescence and red cell haemolysis. Our results suggest that the potential of various environmental particles and mineral fibres to induce inflammation, fibrosis, and cancer of the lung could be related to their ability to induce inflammatory cells to produce reactive oxygen metabolites.

Asbestosis is characterised by a chronic inflammatory reaction of the lung that has been attributed to the interplay of several biological processes at the level of alveoli and interstitium. ${ }^{1-3}$ The occurrence of asbestos related disease is influenced by the type of mineral and the dimensions of the fibres, as well as by the concentration of fibres and the duration of exposure. ${ }^{4}$ The pathogenesis of the disease at the cellular level is largely unknown, although studies have been done on the epidemiology of disease induced by asbestos, ${ }^{56}$ the physico-chemical structure and aerodynamic properties of the fibres, ${ }^{7}$ their deposition and clearance in the respiratory tract, ${ }^{8}$ the in vitro toxicity, and the cellular biological effects of asbestos fibres. ${ }^{9-11}$

Lung injury caused by respirable particles may result either from the direct effects of the pathological agent or as a consequence of an inflammatory cell influx initiated by dust particles. People exposed to asbestos show pronounced neutrophilic and macrophagic alveolitis in the early as well as chronic stages of asbestosis. ${ }^{2}$ When a phagocytic stimulus is recognised, these inflammatory cells undergo metabolic activation which includes the secretion of reactive oxygen radicals. ${ }^{12}$ The products of activated phagocytes (hydrogen peroxide, superoxide, hydroxyl radical, and singlet oxygen) have been implicated in considerable tissue damage such as degradation of DNA, ${ }^{13}$ cytogenetic damage, ${ }^{14}$ degradation of hyaluronic acid, ${ }^{15}$ inactivation of $\alpha$-l-antiprotease enzyme binding capacity, ${ }^{16}$ autoactivation of latent collagenase,${ }^{17}$ destruction of endothelial cells, ${ }^{18}$ and bioactivation of chemical carcinogens. ${ }^{19}$

Reactive oxygen products generated during the respiratory burst associated with phagocytosis yield light which can be measured with chemiluminescence enhanced by luminol. ${ }^{20}$ Using a chemiluminescence assay we studied the ability of quartz and various mineral fibres to induce generation of reactive oxygen metabolites in human polymorphonuclear leucocytes in vitro.

\section{Material and methods}

Polymorphonuclear leucocytes were isolated from heparinised human venous blood samples obtained from apparently healthy adults by Ficoll (FicollPaque, Sweden) density centrifugation. ${ }^{21}$ Sedimented cells were treated with $\mathrm{NH}_{4} \mathrm{Cl}$ for lysis of erythrocytes, washed twice, and suspended in Dulbecco's phosphate buffered saline. ${ }^{22}$ Viability of separated cells assessed by trypan blue exclusion was above $90 \%$.

Chemiluminescence was measured with an automated microcomputer controlled luminometer (LKB-Wallac 1251, Sweden) at $37^{\circ} \mathrm{C}$. The reaction mixture (final total volume $1.0 \mathrm{ml}$ ) consisted of 50 to $100 \mu \mathrm{l}$ of cell suspension (stock concentration 
$5 \times 10^{6}$ cells $\left./ \mathrm{ml}\right) ; 700 \mu \mathrm{l} \quad 10^{-4} \mathrm{M}$ luminol (5-amino,2,3,-dihydro, 1,4,-phtalazinedione, LKBWallac) in Dulbecco's PBS; and 5 to $200 \mu \mathrm{l}$ of mineral fibres suspended in Dulbecco's phosphate buffered saline (stock concentration $1 \mathrm{mg} / \mathrm{ml}$ ). For standard activators of polymorphonuclear leucocytes, we used phorbol myristate acetate (Sigma Chemicals, USA, P-8139) of a final concentration $0.5 \mu \mathrm{g} / \mathrm{ml}$, and 5 to $25 \mu \mathrm{l}$ serum opsonised zymosan (Sacharomyces cervisiae, Sigma) stock concentration $10 \mathrm{mg} / \mathrm{ml}$ (about 64 $\times 10^{6}$ particles $/ \mathrm{ml}$ ). Chemiluminescence was followed for 40 to 60 minutes after particles had been added to the cells. All particles and fibres were tested in parallel within the same experiment, and each experiment was repeated at least three times.

Four UICC (Union International Contre le Cancer) standard reference asbestos samples-chrysotile A, chrysotile B, amosite and crocidolite-were used. The Finnish anthophyllite (PT 311) and wollastonite (FW 325) samples were from Partek Co, Helsinki, Finland; the United States wollastonite (Wilsboro, USA) and the fractionated Fyle quartz sample ( $85 \%$ of particles less than $5 \mathrm{um}$ ) were gifts. ${ }^{23}$ Titanium dioxide (Titan (IV) oxid) was purchased from the Baker Company, Holland (0343).

To test the haemolytic activity of asbestos a $1.5 \%$ $(\mathrm{v} / \mathrm{v})$ erythrocyte suspension was prepared in $0.01 \mathrm{M}$ Tris-hydrochloric acid, $0.15 \mathrm{M}$ sodium chloride buffer, $\mathrm{pH} \mathrm{7.36}$, and incubated with mineral fibres (final concentration $2.0 \mathrm{mg} / \mathrm{ml}$ for two hours at $37^{\circ} \mathrm{C}^{24}$ The optical density of the lysate was measured at $540 \mu \mathrm{m}$. Complete haemolysis was achieved by Triton X-100 to give an optical density of 1.55 for the lysate.

\section{Results}

Human polymorphonuclear leucocytes respond rapidly after challenge with standard stimulants such as phorbol myristate acetate and opsonised Zymosan by activation of the oxygen metabolism and production of chemiluminescence (fig 1). The maximal chemiluminescence is reached after about 10 to 20 minutes and the chemiluminescence response to these activators is dose dependent (not shown). Polymorphonuclear leucocytes also produced chemiluminescence after the addition of particles of mineral fibres to the cells (figs $2 a$ and $b$ ). The peak light intensity was reached in eight to 14 minutes, after which the chemiluminescence decreased. On equal mass basis $(\mu \mathrm{g} / \mathrm{ml})$ quartz, mineral fibres, and titanium dioxide induced chemiluminescence (peak light intensity) in the following order of magnitude: quartz; chrysotile $\mathrm{A}$; crocidolite; chrysotile $\mathrm{B}$; anthophyllite; wollastonite SF; wollastonite USA; and titanium dioxide. The chemiluminescence produced

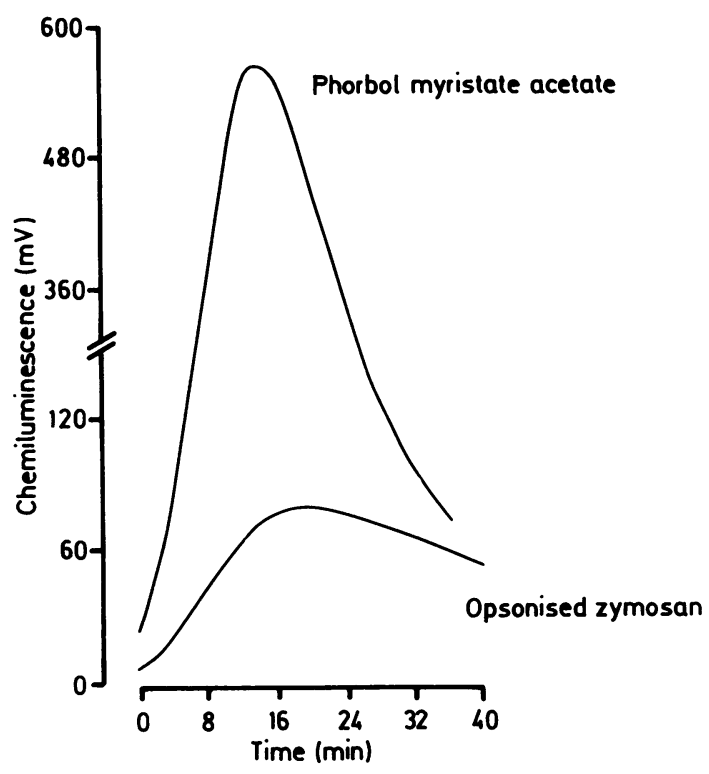

Fig 1 Chemiluminescence response of polymorphonuclear leucocytes induced by phorbol myristate acetate $(0.5 \mu \mathrm{g} / \mathrm{ml})$ and opsonised Zymosan $(100 \mu \mathrm{g} / \mathrm{ml})$ during 40 minutes of incubation.

by wollastonites and titanium dioxide were only slightly above the control background levels. Fig 3 shows the chemiluminescence intensity correlated linearily with mineral fibre and particle concentration ( 5 to $100 \mu \mathrm{g} / \mathrm{ml}$ ).

The chemiluminescence response of various fibres and particles correlated positively to their haemolytic effect on erythrocytes (fig 4), except that crocidolite and amosite had a weak haemolytic effect and caused a relatively strong chemiluminescence response. Titanium dioxide had a negligible effect in both the haemolysis and chemiluminescence tests.

\section{Discussion}

During phagocytosis of particulate matter, polymorphonuclear leucocytes and macrophages produce electronically excited reactive metabolites (such as superoxide anion radical, hydrogen peroxide, and hydroxyl radical), which can damage tissues. ${ }^{12202526}$ Although the precise mechanism by which oxygen derived free radicals and their metabolites cause cell injury is not clear, there is indirect evidence that oxygen free radicals may have a role in asbestos induced inflammation, fibrosis, and cancer. ${ }^{27}$ Intratracheal introduction of specific enzyme substrate systems known to generate oxygen metabolites will cause 

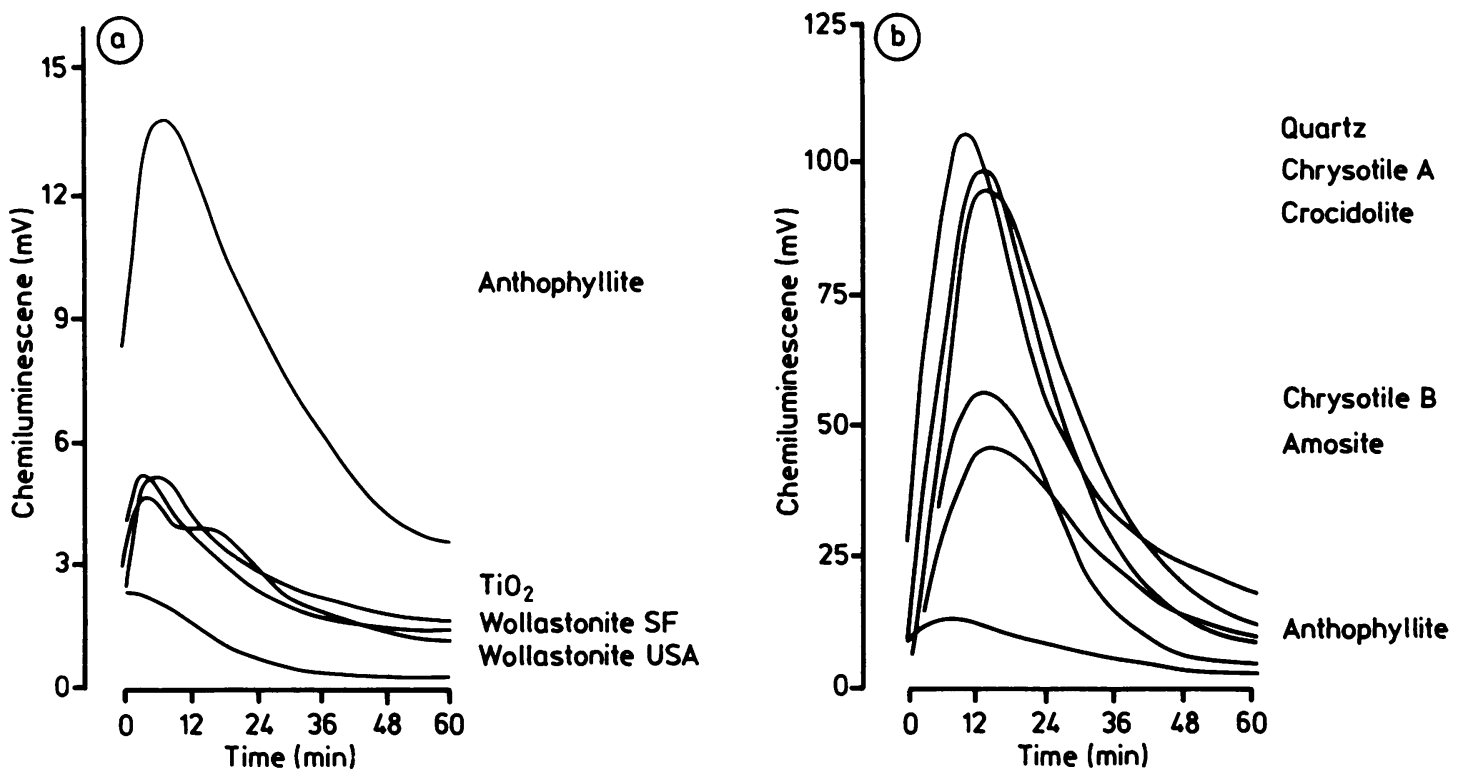

Figs 2a and $\mathrm{b}$ Chemiluminescence response of polymorphonuclear leucocytes induced by $50 \mu \mathrm{g} / \mathrm{ml}$ of quartz, mineral fibres, and titanium dioxide.

acute lung damage. ${ }^{28}$ Production of oxygen free radicals by phagocytes does not necessarily require the engulfment and phagosome fusion process, but it too is initiated by cell membrane activating agents such as phorbol myristate acetate, concanavalin $\mathrm{A}$, and formyl peptides. ${ }^{29}$ The present results suggest that even fibre cell contact will rapidly initiate the generation of reactive oxygen metabolites.

All commercial types of asbestos are associated

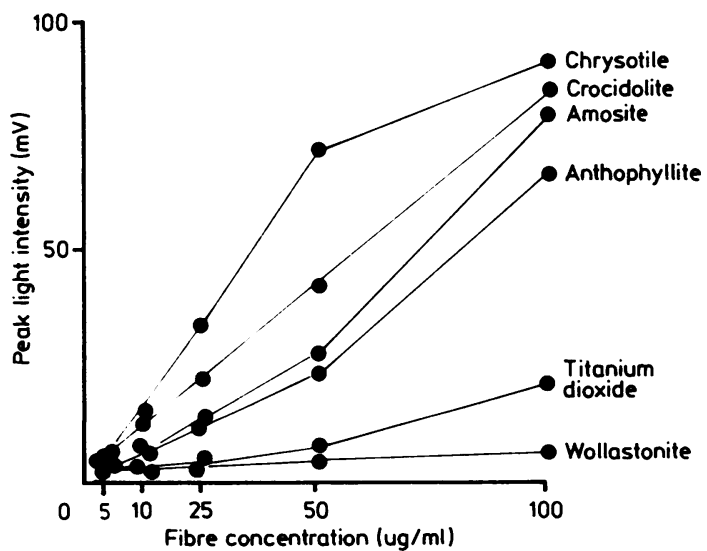

Fig 3 Dose response $(5,10,25,50,100 \mu \mathrm{g} / \mathrm{ml})$ of mineral fibres on chemiluminescence peak light intensity of polymorphonuclear leucocytes. with asbestosis, and a dose-response correlation has been well documented. ${ }^{11}$ Although different fibres produce fibrosis to varying extents, chrysotile, crocidolite, and amosite seem to be more fibrogenic than anthophyllite and wollastonite. ${ }^{3031}$ Titanium dioxide $^{2}$ dusts are generally regarded as biologically inert. This clinical and experimental experience of fibrogenic po-

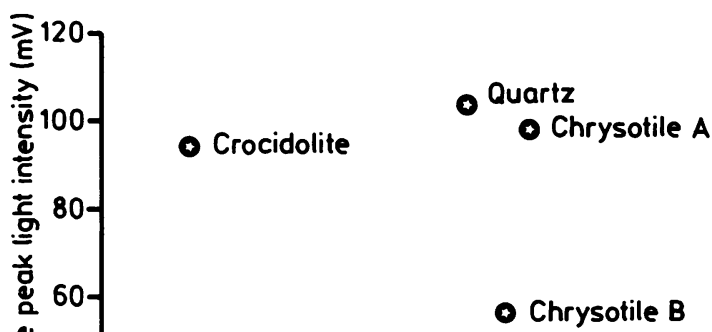

- Amosite

Fig 4 Relation between red cell haemolysis induced by fibres and oxygen free radical production of polymorphonuclear leucocytes. 
tential seems to agree with our data on the ability of mineral fibres to induce polymorphonuclear leucocytes in vitro to generate reactive oxygen products.

All types of asbestos seem to be carcinogenic. Chrysotile, amosite, and anthophyllite are associated with increased risk of lung cancer, ${ }^{11}$ and epidemiological data suggest that exposure to quartz and crocidolite also carries a risk for lung cancer. ${ }^{32} 33$ Crocidolite has the strongest association with mesothelioma. ${ }^{34-37}$ On the other hand, the tumour rarely, if ever, occurs in workers exposed to anthophyllite. ${ }^{4}$ Breakdown of DNA, ${ }^{13}$ lipid peroxidation, ${ }^{38}$ and bioactivation of chemical carcinogens ${ }^{19}$ and cytogenetic changes ${ }^{14}$ occur after exposure of various cell types to generators of oxygen free radicals. The carcinogenic potential of fibres seems to be related to their ability to initiate the production of reactive oxygen metabolites in polymorphonuclear leucocytes.

A variety of biochemical, morphological, and in vitro techniques have been used to document events that might be associated with asbestos toxicity at the cellular level. In vitro haemolysis of erythrocytes has been suggested as a model for the biological activity of dusts. ${ }^{39}$ A correlation seems to exist between haemolytic activity and cytotoxicity, ${ }^{9}$ and it has been suggested that haemolytic activity correlates with fibrogenicity. ${ }^{40}$ The different charge properties of mineral fibres have been suggested to mediate the different haemolytic and cytotoxic effects of mineral fibres. ${ }^{4142}$ The relatively negligible effect of crocidolite on cytotoxicity and haemolysis, despite its obvious fibrogenic and carcinogenic potential, has been little studied. Our study shows, however, that crocidolite initiates as strong a reactive oxygen metabolite response as chrysotile, weight for weight.

Although we cannot directly relate our findings on oxygen metabolites, derived from polymorphonuclear leucocytes to red cell haemolysis and cytotoxicity, the chemiluminescence assay for in vitro testing of mineral dust polymorphonuclear leucocytes interactions may predict the inflammatory and fibrogenic potentials of mineral fibres, including the man-made mineral fibres.

This study was supported by grants from Sigrid Jusélius Foundation and Finska Läkaresällskapet. The financial support of Partek Company is acknowledged. We appreciate the secretarial help of Ms Tuula Kajonen.

\section{References}

1 Heppleston AG. Pulmonary toxicology of silica, coal and asbestos. Env Health Perspect 1966;55:111-27.

2 Bégin R, Cantîn A, Berthiaume Y, et al. Clinical features to stage alveolitis in asbestos workers. Am J Ind Med 1985;8:521-36.

3 Reynolds HY. Lung immunology and its contribution to the im- munopathogenesis of certain respiratory diseases. $J$ Allerg. Clin Immunol 1986;78:833-47.

4 Craighead JE, Mossman BT. The pathogenesis of asbestosassociated diseases. $N$ Engl J Med 1982;306:1446-55.

5 Becklake MR. Asbestos-related diseases of the lung and other organs: their epidemiology and implications for clinical practice. Am Rev Respir Dis 1976;114:187-227.

6 Whitwell F, Scott J, Grimshaw M. Relationship between occupations and asbestos fibre content of the lungs in patients with pleural mesothelioma, lung cancer and other diseases. Thorax 1977;32:377-86.

7 Langer AM, Nolan RP. Physicochemical properties of minerals relevant to biological activities: State of the art. In: Beck EG, Bignon J, eds. In vitro effects of mineral dusts. Berlin: SpringerVerlag, 1985:9-24.

8 Brody AR, Roe MW. Deposition pattern of inorganic particles at the alveolar level in the lungs of rats and mice. Am Rev Respir Dis 1983;128:724-9.

9 Harington JS, Miller K, Macnab G. Hemolysis by asbestos. Environ Res 1971;4:95-117.

10 Harington JS, Allison AC. Tissue and cellular reactions to particles, fibers, and aerosols retained after inhalation. In: Lee DHK, Handbook of physiology. Section 9. Reactions to environmental agents. Bethesda: American Physiological Society, 1977:263-83

11 Vallyathan V, Green FHY. The role of analytical techniques in the diagnosis of asbestos-associated disease. CRC Crit Rev Clin Lab Sci 1985;22:1-42.

12 Fantone JC, Ward PA. Role of oxygen-derived free radicals and metabolites in leukocyte-dependent inflammatory reactions. Am J Pathol 1982;107:395-418.

13 Birnboim HC. Factors which affect DNA strand breakage in human leukocytes exposed to a tumor promotor, pharbol myristate acetate. Can J Physiol Pharmacol 1982;60:1359-66@

14 Weitberg AB, Weitzman SA, Destrempes M, Latt SA, Stossel TP Stimulated human phagocytes produce cytogenetic changes in cultured mammalian cells. $N$ Engl J Med 1983;308:26-30.

15 Greenwald RA, Moy WW. Effect of oxygen-derived free radicak on hyaluronic acid. Arthritis Rheum 1980;23:455-63.

16 George PM, Travis J, Vissers MCM, Winterbourn CC, Carrell RW. A genetically engineered mutant of alfa-l-antitrypsin protects connective tissue from neutrophil damage and may be useful in lung disease. Lancet 1985; ii:1426-8.

17 Weiss SJ, Peppin G, Ortiz X, Ragsdale C, Test ST. Oxidative autoactivation of latent collagenase by human neutrophils. Science 1985;227:747-9.

18 Sachs T, Moldow CF, Craddock PR, Bowers JK, Jacobs HS. Oxygen radical mediated endothelial cell damage by complement-stimulated granulocytes: an in vitro model of immune vascular damage. J Clin Invest 1978;61:1161-7.

19 Dix TA, Marnell LJ. Metabolism of polycyclic aromatic hydrocarbon derivatives to ultimate carcinogens during lipid peroxidation. Science 1983;221:77-9.

20 Allen RC, Stjernholm RL, Steele RH. Evidence for the generation of an electronic excitation state(s) in human polymorphonuclear leukocytes and its participation in bactericidal activity. Biochem Biophys Res Commun 1972;47:679-84.

21 Bøyum A. Separation of leucocytes from blood and bone marrow. Scand J Clin Lab Invest 1968;21suppl 97:1-109.

22 Weening RS, Roos D, Loos JA. Oxygen consumption of phagocytizing cells in human leukocyte and granulocyte preparations: a comparative study. J Lab Clin Med 1974;83:570-6.

23 Tossavainen A. Determination of quartz on membrane filters by X-ray diffraction. Scand J Work Environ Health 1979;5: 379-85.

24 Nolan RP, Langer AM, Harington JS, Oster G, Selikoff IJ. Quartz hemolysis as related to its surface functionalitis. Environ Res 1981;26:503-20.

25 Halliwell B, Gutteridge JMC. Oxygen toxicity, oxygen radicals, transition metals and disease. Biochem J 1984;291:1-14. כ . (n) (n)

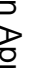

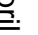
N U N 可 으 (ำ ( ) 뭉 
26 Rossi F, Bellavite P, Berton G, Grzeskowiak M, Papini E. Mechanism of production of toxic oxygen radicals by granulocytes and macrophages and their function in the inflammatory process. Path Res Pract 1985;180:136-42.

27 Anonymous. Metal chelation therapy, oxygen radicals, and human disease. [Editorial]. Lancet 1985;i:143-5.

28 Johnson KJ, Fantone JC, Kaplan J, Ward PA. In vivo damage of rat lungs by oxygen metabolites. J Clin Invest 1981;67:983-93.

29 Allen RC. Reduced radical and excited state oxygen in leukocyte microbicidal activity. Frontiers of Biology 1979;48:197-233.

30 Huuskonen M, Tossavainen A, Koskinen $\mathrm{H}$, et al. Wollastonite exposure and lung fibrosis. Environ Res 1983;30:291-304.

31 Hanke W, Sepulveda M-J, Watson A, Jankovic J. Respiratory morbidity in wollastonite workers. Br J Indust Med 1984; 41:474-9.

32 Weill H, Hughes J, Waggenspack C. Influence of dose and fiber type on respiratory malignancy risk in asbestos cement manufacturing. Am Rev Respir Dis 1974;120:345-54.

33 Koskela R-S, Klockars M, Järvinen E, Kolari PJ, Rossi A. Cancer mortality of granite workers. Scand J Work Environ Health 1987;13:26-31.

34 Wagner JC, Sleggs CA, Marchant P. Diffuse pleural mesothelioma and asbestos exposure in North-Western Cape Province. $\mathrm{Br} J$ Ind Med 1960;17:260-71.

35 Selikoff IJ, Hammond EC, Churg J. Carcinogenicity of amosite asbestos. Arch Environ Health 1972;25:183-6.

36 Becklake MR. Exposure to asbestos and human disease. $N$ Engl $J$ Med 1982;306:1480-2.

37 McDonald JC, McDonald AD. Epidemiology of mesothelioma from estimated incidence. Prev Med 1977;6:426-46.

38 Chow CK, Tappel AL. An enzymatic protective mechanism against lipid peroxidation damage to lungs of ozone-exposed rats. Lipids 1972;7:518-21.

39 Macnab G, Harington JS. Hemolytic activity of asbestos and other mineral dusts. Nature 1967;214:522-3.

40 Hefner RE, Gehring PJ. A comparison of the relative rates of hemolysis induced by various fibrogenic and non-fibrogenic particles with washed rat erythrocytes in vitro. Am Ind $\mathrm{Hyg}$ Assoc J 1975;36:734-40.

41 Mossman BT, Light W, Wei E. Asbestos: mechanisms of toxicity and carcinogenicity in the respiratory tract. Ann Rev Pharmacol Toxicol 1983;23:595-615.

42 Light WG, Wei ET. Surface charge and asbestos toxicity. Nature 1977;265:537-9.

Requests for reprints to: Matti Klockars, Institute of Occupational Health, Topeliuksenkatu 41 a A, SF-00250 Helsinki, Finland. 